\title{
Teacher Education Partnerships: Integration of Case Studies within an Initial Teacher Education Program
}

\author{
Darlene Ciuffetelli Parker \\ Brock University \\ Deirdre Smith \\ Ontario College of Teachers \\ Patricia Goldblatt \\ Independent Consultant
}

\begin{abstract}
This paper outlines the partnership between the Faculty of Education at Brock University and the Ontario College of Teachers as the self-regulatory body for the teaching profession in Ontario. The paper explores how two institutions collaborated to use case study methodology with faculty members in an initial teacher education program. The paper explores the planning and delivery of a case study institute to faculty members of the Teacher Education Department at Brock University and how self-study was incorporated to reflect on the partnership. This paper details the partnership and the links between self-study of teacher education practices and the constructivist approach of case study methodology.
\end{abstract}

Darlene Ciuffetelli Parker, Ph.D., is an Assistant Professor in the Teacher Education Department at Brock University. Her research interests include narrative inquiry research methods, teacher education practices, and programmatic complexities related to poverty and education. Email: darlene.ciuffetelli-parker@brocku.ca

Deirdre Smith is the Manager of the Standards of Practice and Education division of the Ontario College of Teachers. In this capacity, she has led provincial teacher education policy development and research initiatives that support a collective vision of professionalism as articulated in the ethical standards and standards of practice for Ontario's teaching profession

Dr. Patricia F. Goldblatt is a former program officer from the Ontario College of Teachers in Ontario and secondary teacher in Toronto. Her articles, books and essays that focus on education, women's issues and narrative research have been published locally, nationally and internationally.

Brock Education, Volume 18, No. 2, Spring 2009, 96-113 


\section{Teacher Education Partnerships: Integration of Case Studies within an Initial Teacher Education Program}

This paper outlines the partnership between the Faculty of Education at Brock University and the Ontario College of Teachers as the self-regulatory body for the teaching profession in Ontario. The paper explores how two institutions collaborated to use case study methodology with faculty members in an initial teacher education program. The paper explores the planning and delivery of a case study institute to faculty members of the Teacher Education Department at Brock University and how we used self-study and case methodology to reflect on our partnership.

As authors of this paper we each reflected on the process of our partnership from its inception, to the culminating event of the case study institute at the Faculty of Education, to the reflection of the data received from participants of the institute. In this manner, we participated in a self-study (Loughran, 2004) of our teacher education practices on the use of case studies for pre-service teacher education, as well as by our reinterpretation of the critical events that took place in the partnership process of the case study institute. This paper details our partnership and the links between self-study of teacher education practices and the constructivist approach of case study methodology.

\section{Context}

Forty faculty members attended a case study institute that was organized by a member of the faculty of education and two members of the certification institution. The institute participants, comprised of full time tenure-track and tenured professors as well part time instructors, acted as advisors to teacher candidates during their practicum as well as during a practicum course in the Teacher Education Department at Brock University. To plan the institute, we (one faculty member representing the Faculty of Education and two self-regulatory members representing the Certification Institution) met for one full day. Afterward, we consulted throughout the planning process via email and phone correspondence. Our conversations focused primarily on teacher education practices with attention on the use of case studies. After we delivered the institute as a collaborative team, we reviewed data received from the participants of the institute. We then considered the entire process by reflecting together and individually.

Each aspect of the institute provided opportunities for us to dialogue and consider how our institutions' goals could be achieved. This involved the selection of relevant cases, to the collection of data through informal observation and charts to record participant thoughts (Guskey, 2002) provided opportunities for us to dialogue and consider how our institutions' goals could be achieved. As well, our reinterpretation of the critical events that took place in the process of our partnership of the case study institute aided in building future relationships between the faculty and self-regulatory body. We elaborate on this partnership and provide further context from the perspective of the Faculty of Education at Brock University and from the perspective of the Ontario College of Teachers.

\section{Faculty of Education at Brock University Perspective}

In the Teacher Education Department at Brock University, becoming a teacher is both an exciting and complicated journey. There is a constant pull and tug of merging theory into practice, practice into theory, and preparing new teachers in a very short time span. To ease these 
tensions, Dr. Darlene Ciuffetelli Parker, was appointed as the coordinator of the Elementary Foundational Methods course. Darlene's role was to revise the Methods course of the teacher education program and contemplate how the complementary methods cohort seminar could merge better the theory practice divide. Darlene turned to the idea of case study to merge method theory topics to seminar practice topics. Using narrative cases of real teachers would dramatize the issues that teaching candidates might encounter in their classes and prepare them in practical ways (Sykes \& Bird, 1992; McAninch, 1993; Merseth, 1997; Richert, 1991). Darlene then began a project to edit a case study book which matched methods topics to real life case scenarios in classrooms, schools and educational communities across Ontario. The idea was to incorporate cases in the cohort seminar where skilled faculty members could aid the facilitation for teacher candidates and use their own skilled knowledge and experiences to stimulate a rich theory practice discourse (Shulman, 2002). Emulating a reflective and collaborative stance would help beginning teachers guide their decision-making processes (Cochrane-Smith, 2002).

During the planning stages with the staff from the Ontario College of Teachers, Darlene recognized that the cohort faculty members required training in case pedagogy. The Ontario College of Teachers employed cases as a means to implement the standards of practice. Darlene had observed Deirdre Smith's and Patricia Goldblatt's in-service presentations and heard their presentations at CSSE and AERA.

Darlene revised the Methods course outline to include the foundational standards for the teaching profession that was developed by the Ontario College of Teachers. She had many conversations in and around this revision with Deirdre and Patricia early on. Subsequently, she contacted both Deirdre and Patricia and invited discourse on the topic of case study use for the cohort seminar. Their partnership grew and it focused on collaboratively delivering a case study institute for the Teacher Education Department at Brock University.

The self-regulatory body for teachers was responsible for certification, ongoing education of their members in the province, and ensuring that teachers were aware of the standards. Several resources such as a casebook (authors, 2003) had been developed, written in teachers' own words, and with cases commentaries. The two members of the self-regulatory body with whom Darlene worked in this study were the authors of the casebook, had documented the successful impact of using cases and had raised standards awareness with the teachers. Since Darlene knew and incorporated the standards of practice into her foundational methods course, there was positive collaboration between herself and the staff of the self-regulatory body. However, Darlene took the lead in ensuring that the case, the protocol, and the methodology, would be welcomed by faculty members during the institute. Intent on ameliorating how the Methods Course could be made more relevant to pre-service teachers, but also to provide in-service for faculty members, Darlene's vision was aimed at enhancing the way classes at both faculty, and in schools were taught: augmenting teacher education through case pedagogy. Her partnership with the Ontario College of Teachers was pivotal to this vision.

\section{Ontario College of Teachers Perspective}

Supporting the integration of the [regulatory body of standards] within teacher education and providing for the ongoing professional learning of teachers are key objects of the Ontario College of Teachers. Ontario College of Teachers staff supports the ongoing attainment of both of these objects. They collaborate with the programs of Professional Teacher Education to authentically infuse the profession's standards within initial teacher education courses and 
practicum experiences. These standards are one of the criteria set out in regulation for the Accreditation of teacher education programs in the province of Ontario. Case inquiry proved to be a relevant and meaningful process for accomplishing these goals as many Faculties of Education were using the extensive set of Ontario College of Teachers case resources as pedagogical and curriculum resources.

Darlene was responsible for revising the methods course in the faculty's teacher education department: a course outline closely connected to the practicum (cohort) seminar at Brock University's Faculty of Education. She recognized the potential of the Ontario College of Teachers' case resources for enhancing the practicum cohort model. A few of Darlene's colleagues had previously worked with the Ontario College of Teachers staff in the use of cases to support teacher induction. Thus, with these connections, Darlene contacted the Ontario College of Teachers to seek further partnership.

Darlene engaged in several conversations with Ontario College of Teachers staff, Deirdre and Patricia, regarding the use of the Ontario College of Teachers case materials within teacher education. The cohort seminar appeared to be an authentic forum for integrating the standards through the use of the Ontario College of Teachers' case materials. The cohort seminar appeared to be the ideal context for linking practice and theory through case methods and the standards.

It became very evident that a collaborative professional learning project involving both the Ontario College of Teachers and Brock University could result in the revitalization of the methods courses and cohort seminar and successfully meet the objects of the Ontario College of Teachers. Once we mutually recognized that both institutes' goals could be attained and effectively addressed through collaboration, through this project, we immediately worked to conceptualize a joint plan.

Darlene worked with support from the Chair of her department as well as the Dean of Education. She edited a case study book, which contained many cases from the Ontario College of Teachers; and she facilitated the idea of a plan for a professional learning session in case pedagogy for all faculty responsible in teaching the cohort seminar. Deirdre worked with the Registrar of the Ontario College of Teachers to provide access to its published and unpublished case resources.

\section{Theoretical Framework}

\section{Self-study}

Self-study is a methodology characterized by examination of the role of the self and "the space between self and the practice engaged in" (Bullough \& Pinnegar, 2001, p. 15). According to Bullough \& Pinnegar (2001), it is through reflection and teacher conversations, that we negotiate the tensions between ourselves and our contexts; between biography and history. Among the attractions of self-study to the partnership of the self-regulatory body and the faculty of education are notions that self-study is highly compatible with other qualitative research methodologies and it focuses on substantive issues of importance to teacher educators (Zeichner \& Noffke, 2001).

While self-study is primarily a personal inquiry, we benefitted by working as collaborators to step outside ourselves in order to notice collaboration and partnership in our work. The case study institute was an opportunity for us to build on our partnership and work in teacher education. In this manner, self-study became an integral part of our own professional 
practice as teacher educators and evoked "deeper understandings of the aims, methods, and outcomes of [our] work with beginning teachers" (Dinkelman, 2003, p. 8). The manner in which we worked was important for future expectations, needs and practices not only to teacher candidates but to our own future practices as well (Korthagen, Loughran \& Russell, 2006).

Self-study is a methodology in this paper that has helped us to examine our own roles as collaborators, as well as individuals in the planning of the case study institute, hand "the space between self and the practice engaged in" (Bullough \& Pinnegar, 2001, p. 15). Building relations in a partnership, particularly between a faculty of education and a self-regulatory body, is committed work. Our work together offers perspective and unites the aspect of reflection on our own teacher education practices while also promoting a constructivist and reflective strategy, such as case methods, for use in an initial teacher education program. We explain further case methodology.

\section{Case Methodology}

Case methodology functions as a central inquiry process as teachers position themselves and their knowledge as central to their focused inquiry. Teacher cases present holistic descriptions and provoke analysis of a single instance, phenomenon or social unit (Merriam, 2001). Educators' conversations provide the basis for social interchange (Dewey, 1938) that facilitates "teacher talk" and collaborative communities form for the purposes of stimulating meaningful dialogue. Because those dialogues were sparked by first person descriptions of dilemmas in cases are personal and professional (Connelly \& Clandinin, 1988). We reasoned that constructing knowledge with other teachers, would aid in raising personal awareness and foster deepening understanding of their lives as professional educators. Like the methodology of selfstudy, case methodology is a uniquely constructivist approach to learning about and reflecting on practice. We found this connection useful as we planned and implemented the case institute.

Cases also are qualitative processes that allow teachers to gain in-depth understanding of themselves in particular situations, such as school cultures.

Engaging in analysis, structuring it on reflection of experiences (Korthagen, 2001), is essential for the development of professional knowledge to inform effective practice. The re-construction of stories, dialogues and commentaries surrounding the narratives results in professional conversations (Rust, 1999) that expose diverse views, created in communities of inquiry and self-study (Loughran, 1999; Korthagon, 2004). We adapted the case discussion models set out by Judith Shulman (Shulman, Whittaker, \& Lew, 2002; Shulman, 1992) in order to develop a unique protocol and structure that integrates the Ontario College of Teachers' standards into the process. Charts were created to align with our strategies of and to deepen knowledge of the standards. To link the theory of the standards and concrete descriptions of practice, we looked for evidence of evocative rich, "thick description" (Geertz, 1973) in responses, and in the animated discussions of educators' lived experiences to which served as catalysts for participants to remember these sessions at a later date.

As a means to improve practice, we were aware of the benefits of cases in planning for future dilemmas, as sites for reflection, inquiry and dialogue regarding educational issues, for linking theory to practice, and supporting teachers as navigators of their own practice (Sykes \& Bird, 1992; McAninch, 1993; Author \& Author, 2004). Cases then became professional learning texts to be shared with others, used as both curriculum and pedagogical resource within teacher education. 


\section{Data Set}

We draw on a variety of data sources such as: responses from participants of the case study institute; our own reflections of the partnership process; our reflections after the case institute was completed; and, other artifacts such as letters of appreciation and input from other stakeholders. By collecting this data from our institute planning and final outcome of the case study institute, we were able to deepen our understanding of ourselves as collaborators and teacher education practitioners and what that meant for each respective partner. In the following section we describe the case institute session and new understandings from our respective positions.

\section{The Case Study Institute for Faculty Within an Initial Teacher Education Program}

In the early spring of 2007, forty elementary full and part time faculty members at Brock University had the unique opportunity to participate in a full day case study institute with Ontario College of Teachers staff. Faculty discussion supported cases as touchstones that provided teacher candidates with an opportunity to anticipate real life scenarios of school and to use their growing knowledge to resolve tensions alongside peers and faculty in the cohort seminar.

The use of cases to create powerful and substantial opportunities for learning was anticipated as a bridge between the theory practice divide. Cases were seen by faculty as a constructivist approach to theory and practice which encourages teacher candidates to use their own learning and active participation in solving the everyday dilemmas teachers face in Ontario schools today. The following is a description of the methodology of case use during the institute.

\section{Analysis of Case Methodology with Faculty Members}

We carefully selected a case entitled, A Student Teacher faces the Challenges of the Classroom (Author \& Author, 2005) that we anticipated would meet the needs of this group. Because faculty advisors function as mentors and supports to pre-service teachers, we chose a narrative, written by a first year teacher that focused on the burgeoning identity and self-doubt experienced by an ingénue. The case describes an associate teacher who is absent while the teacher candidate faced classroom management and supply teacher dilemmas. As well, tensions that impinge on the teacher concerns gender, power struggles, and hierarchies within the school environment.

This case has been used successfully with numerous pre-service groups and teachers in their beginning years of teaching. We have noted that each teacher must determine the needs and exigencies of their own practice, and through our case process we added relevant commentaries so that participants can understand that there is never only one way to deal with an issue.

The Ontario College of Teacher's cases, all written by teachers in their own voices, are always accompanied by three to five commentaries that offer diverse interpretations of the situations presented in the case. To complement this particular case used with the faculty members, we provided three commentaries written by a professor, a researcher and a dean from Ontario, Alberta, and Columbia University. Case commentaries can provide catalysts in initiating the construction of knowledge relevant to teacher education. Through interpretation, teachers might blend what was present and what could be imagined (Moustakas, 1994) in their own 
settings. Commentators' interpretations serve as catalysts for resources and insights to deepen understandings of issues that occur in educational settings. We were mindful of the role commentaries have played in probing dialogues into teacher education issues, thinking of Perkins \& Saloman's (1998) "bridges" but also "hugs' between disparate elements that encourage revelations in learning.

Next, we invited participants to use the standards of practice and the ethical standards as lenses in recognizing how the teacher in the case was living out the standards in the story, and how the standards might help in providing redress to the multiple issues. We believed in "situated knowledge" (Bruner, 1990) and thick description (Geertz, 1973) that would lodge in participants' minds because the stories were situated in emotional struggles. Our process concerned building knowledge of facts as the basis for generating issue but the process was also immensely reflective and engaged the faculty members in an active constructivist framework as they read, reacted and enacted the case. The conversations and facial expressions were lively as faculty members affirmed that the case narrative was very credible. They shared that they, themselves, had experienced similar incidents with associate teachers in their first years of teaching. The room was abuzz with interesting and meaningful conversations about professional practice related to the case.

Two participants stopped the process to ask questions and asserted that they had already been working with cases. Although using cases was not new to this group, our theoretical framework that reflected Judy Shulman's (Shulman, Whittaker \& Lew, 2002) case discussion process differed from other pedagogies they had experienced. We noted a moment of tension from one faculty member who dismissed case study as frivolous, but Darlene addressed the situation and explained that cases can and have been used in different ways for teacher education programs across Ontario. She acknowledged that cases were not unknown but had not been used previously in her own cohort group. The tension between theory and practice was discussed and the majority of faculty members agreed that case methodology was a positive step in the right direction.

We then divided the group into three sections. Each small group read one commentary and synthesized the points. Then, one person per small group, voiced the commentator's perspective with the entire group. After every monologue, the entire group discussed the response, acknowledging, refuting, comparing or contrasting it to the others they had heard. Once more, talk was spirited and thoughtful as participants underscored the importance of the lessons being offered in the wise writings of the commentators. Another incidence of tension occurred as some participants grappled with one of the commentaries on how to affect change in educational landscapes (Connelly \& Clandinin, 1988). This was a concept that required deeper discussion as there were metaphors, proactive strategies and philosophical underpinnings that differed from some of the very practical and concrete recommendations in the other two commentaries. Once more, Darlene, having worked with a variety of faculty members, provided feedback and practical meaning to the metaphorical commentary.

We believed in the importance of multiple, varied and diverse responses to cases because of the variety of levels and experiences participants bring to the sessions. As well, this was an opportunity for ongoing learning: the "messiness" (Newman, 1987) of inquiry often yields wonderful rewards and ways to reconsider and reframe issues in practice. Providing several commentaries ensures that there is never only one way to consider an issue in a case.

In the next section, we provide our reflection/s of the process of planning and carrying out our case institute. New understandings about teacher education practices through case study 
methods, as well as our partnership, are presented by each one of us. Themes include: revisioning in the faculty of education; leadership within institutions; and; reflective practice of institutional partnerships. Each theme is written in the voice of the author to represent either the faculty of education or the self regulatory body.

\section{New Understandings}

\section{Re- visioning in the Faculty of Education: Darlene's Reflection}

a) Re-visioning and strengthening foundational courses : using cases

When I was hired as a new faculty member, I was immediately given the mandate as a coordinator to revise the foundational methods course and to link new and revised methods topics to our cohort seminar course. This seemed, at best, a large if not impossible feat. In retrospect, my new understanding of the use of case pedagogy over the last two years has strengthened not only my own teacher education practices but has also bridged new partnerships with the selfregulatory body. The professional knowledge of case methodology and the work that the selfregulatory body had invested in throughout Ontario was a significant resource and timely strategy for use in our teacher education program. I was able to not only strengthen the foundational methods course but also to provide further insight about case usage to faculty members. Still, tensions were cited from 2 members during the institute and I wondered what they signified from various perspectives? Did faculty members feel "regulated" after the institute to then use only case pedagogy in their cohort seminar; or, were they perhaps feeling tension between their own academic freedom and the recommendation to "change" their seminar course? Were others, like so many in-service teachers during professional development workshops, feeling the pressure to do "even more work", given the extensity of the work that is already required? These perspectives came to the surface for me as a co-ordinator still on the brink of re-visioning program.

\section{b) Necessary support}

I was supported throughout the process of re-visioning the methods course in my first year of tenure by the Chair of my department. As well, the Dean acknowledged my leadership role and understood its complexity as it was related to the cohort seminar for our entire department. I already had forged personal links with staff at the self-regulatory body, when I, myself, had presented at CSSE in June 2006. They had demonstrated the effective use of case pedagogy. I immediately made links to: a) my own practice and narrative work in teacher education, and b) foresaw the potential for new possibilities for case pedagogy in the foundations course and cohort seminar These first insights encouraged the pathway for my in-depth work in creating a supplementary case book resource for the cohort seminar as well as for conceiving of a faculty partnership with the Ontario College of Teachers.

The ensuing support from both the Chair of the Teacher Education Department as well as the Dean of Education affirmed my leadership role and further suggested to me that there was definite promise in cases to impact on our methods' course and on faculty. This motivated my own moral and positive momentum in working with Deirdre and Patricia and on my faculty work in creating the partnership throughout these two years. Further, the acknowledgment of our 
partnership in other venues such as faculty meetings, conferences and other professional development spaces, ensured the sustainability of our work for the future.

c) Personal and professional insights

I have learned, through this collaboration with the Ontario College of Teachers, that my own teacher education practices for the profession have been illuminated, supported and renewed in partnership with others. My own in-faculty work in other courses, research and other collaborations with colleagues, has been strengthened through this experience. I have shifted my frame of reference to include wider perspectives and broader narratives of practice, now embedding them in my own teacher education practices. In a recent concurrent education program retreat with faculty members, I shared these insights as a personal perspective to revision the future of our five year concurrent education program. The ideas were very well received by faculty members. I have come to understand, through my own self-study of this partnership venture with the Ontario College of Teachers, that change and momentum can be effective when a partnership is authentic and possesses a vision towards success of both institutions. I have learned that affirmation of successful work is also an indicator for success in future partnerships. Subsequent to the case study institute, the Ontario College of Teachers wrote a letter to the Dean of Education outlining the successful partnership by both institutions and how the partnership has benefit and encouraged future relationships. In turn, the Dean responded with an affirmation for leadership as witnessed by both institutions and an acknowledgement that our work with the Ontario College of Teachers is valuable and has implications for all programmatic success in the future.

\section{The Significance of Leadership: Deirdre's Reflection}

The role of senior leadership

This professional learning project provided several insights for me as an Ontario College of Teachers staff member working with a Faculty of Education. It illustrated the importance of having senior leaders in an organization actively involved in an initiative. The presence of both the Dean of Education and the Program Chair at the institute conveyed support for the collaboration, elevated the importance of the project and communicated a clear message regarding the value of the standards and case inquiry. The visibility and participation of these organizational leaders were significant in climate and tone of the institute.

The Dean initiated the session by expressing his commitment to the direction undertaken by DR.P regarding the proposed revision to the cohort seminar. He then connected the profession's standards to the vision and mission of the Faculty of Education. The Dean his opening remarks by stressing the importance of case inquiry. The investment of time on the part of this Dean of Education and his well crafted message honored the past and future work of the faculty as he communicated respect for and belief in his faculty to work together towards common goals in teacher education. He encouraged faculty to use or adapt the Ontario College of Teachers' resources in relevant ways, based on their own individual contexts and teaching philosophies.

The leadership, commitment and interest of the senior leaders in this project reinforced the importance of having all levels of both organizations involved in initiatives that are deemed 
important and central to its mission. The value given to teacher education was conveyed in word and action by those in leadership roles in this Faculty of Education. This project illuminated the importance of senior leaders providing visible support to faculty members that have been delegated the responsibility of facilitating organizational change that involves collaboration with external partners.

\section{Reflecting on Institutional Partnerships: Patricia's Reflection}

In thinking about this partnership, I was conscious of the benefits of a process that continued to generate discussion and deepen awareness as I reviewed the feedback forms that highlighted the faculty advisors' new insights. Because a close working association had developed, we were privy to the thinking and instructional processes at a faculty. As staff at the self-regulatory body, we could be assured that the standards had become a foundational piece, and that our case resources were being used. In this way, we could reflect on the applicability of the standards' implementation. That Darlene was promoting this approach reassured us that we had been on the right track.

Participant faculty advisors documented in writing what we had heard in their conversations. The group reported that the standards had been brought to life for them; they saw the connections between the cases and their own professional practices. They realized the links between the ethical standards and the standards of practice, and wrote that they now felt more comfortable using the "terminology" of the standards. They could assert that the sessions had "heightened my awareness of the standards of practice and the importance of using them as a basis for all cohort group sessions."

As well, participants approached the sessions from a global perspective that spoke to the place of the standards in teacher education and teachers' roles in that context, but also to a more localized level of "teacher's [everyday] realities". Several stated that they felt the cases "reinforced knowledge with a new perspective." The words "reinforced" and "perspective" conveyed that faculty members had understood the purpose of the commentaries and the open dialogues to make personal meaning from the case process. The majority of responses endorsed this perspective.

a) the importance of using teachers' own language

We were pleased that faculty had confirmed "the effort and thought that went into the development of the document." We were hopeful that participants could acknowledge and incorporate case pedagogy as their own, even after leaving the one day session. Teacher acceptance and acknowledgement of the standards and case pedagogy empowered us to proceed in our established implementation direction as once again, teachers asserted their special status as "insiders" who know what teachers need to know (Cochran-Smith \& Lytle, 1990).

\section{b) The availability of resources}

The written feedback conveyed excitement as participants used the word "relevance" over and over again to describe how they would implement the "tools and techniques" that [the selfregulatory body ] had developed and made to teachers. Some participants remarked that the resources "were ready to go". 
Participants stressed that the standards themselves were valuable documents because they "share our values and beliefs" and will aid the development of "a learning community". As a small partnership collaborative community ourselves, we reflected that we modeled our process as we shared our values and beliefs and deepened our understanding of one another and our institutions. By using inquiry-based processes, participants lauded "problem-solving" as an excellent educational strategy because of the role each teacher can play in their own professional milieu of teaching. They were now aware that multiple intelligences had been honoured in the institute and that the resources provided a diversified approach to problem solving.

\section{Replicating and enhancing process}

As a group, faculty described how they would replicate our methodologies and they ventured beyond our work to conceptualize "on-line forums...online courses...cohort group blog" and "focus-groups". They reinforced how cases could be foundational in talking about teacher education. Their feedback targeted the usefulness of cases, especially in thinking about "common goals." They reflected that they could use cases "during orientation of program and in cohort seminars...in P.D. sessions-teacher educators, or retreats" (sic)...self-reflection opportunities" One participant suggested, "Use the standards as a filter for debriefing after a micro-teaching lesson" or "...as a way of reflecting upon practice teaching experience." Another commented that s/he would model "role playing of the writers of the commentaries." Several also recommended "a new course emphasis/orientation" of "tying things back to the standards." The group speculated beyond their own classes' needs to consider "sharing within the faculty"... and globally, "use the standards as a way of reflecting upon teaching practice experience." These responses demonstrated to us the multiple ways the information and case processes could become meaningful to the practices in the context of teacher education.

c) The role of making emotional connections

Exhibiting enthusiastic involvement and passion, the group interaction suggested that ongoing learning would likely be replicated or used in their classrooms (Guskey, 2002). We were gladdened to hear participants acknowledge the role of the Ontario College of Teachers as "proactive". Once more, we could be assured that the strategies we had chosen for implementation were not frivolous. The case process really did work towards enhancing teacher knowledge. Faculty would embrace a methodology because it was based on teachers' lived experiences and situated teachers as their own experts.

Conceptually, many participants reflected on their new insights as a multilayered process. The following statement suggests that the writer has gone deeply into thinking about the experience by finding a resonating simile of an onion to capture the experience,

The case study approach has countless opportunities. The layers of analysis are multifaceted. Just like peeling away the layer of an onion, there is yet another layer or strata of discussion (possible dilemma) to be explained. This could/would lead to extremely meaningful and focused dialogue within the classes. 


\section{d) Planning for the future}

One faculty member's recommendation on extending cases through technology such as in blogs and on-line, suggested possible venues and potentially new ways to think about communicating and collaborating with educators across the province...

Aside from formal repercussions of using cases, we had begun to build strong networks and models for collaboration with Brock University's faculty of education. We were proud to build bridges because we knew that, by sharing insights and information in a collaborative partnership, we could work towards improving teacher education in the province.

\section{e) Modeling a collaborative spirit}

As documented through oral and written responses, the faculty participant understood us to be a cohesive and collaborative team who modeled strategies, passion and ongoing professional learning in teacher education. The presentations appeared effortless. Participants answered one another's questions, or providing direction or assistance when needed. Faculty seemed to appreciate our relaxed and inviting approach in which no one person dominated.

\section{Educational Significance}

In the following, we offer educational significance of our case study institute from the perspective and impact of work of the faculty of education and the self regulatory body. Then, in our conclusion, we discuss the usefulness of collaborative partnerships in general.

\section{Impact for Work of Faculty of Education}

The partnership with the Ontario College of Teachers and the Faculty of Education at Brock University is a valued and significant relationship. The example in this paper of a partnership towards a culminating event such as the case study institute, illustrates how diverse institutions might strive together for the common good of initial teacher education in Ontario and how this importance can be reflected at both the Ontario College of Teachers and Brock University.

As I looked at my own work with Deirdre and Patricia, I reviewed their feedback on our work and invited them to visit our cohort seminars while case studies were conducted. I continued to approach various cohort groups and learned that many educative events have taken place, including other faculty members' presentation of their experiences of case study work in our cohort group at the Ontario Ministry of Education/Faculties conference in Toronto (May 13, 2008). Further, the Dean of Education was invited by the Ontario College of Teachers to speak at a special session about his vision of our partnership in the future. These examples indicate that partnerships between teacher education programs and their educational partners must and should be grounded first in relationships of trust, commitment and a common goal for both institutions.

For the faculty of education, the impact of this institute has opened doors for all faculty members to embrace the standards of practice in other course work beyond the cohort seminar. Embedded is the notion that we are one faculty working towards a common vision. Our short term goal of using case pedagogy with our teacher candidates, through work with the Ontario College of Teachers strengthens the commitment by all faculty instructors to incorporate case pedagogy in new courses and programs. At the same time, we have paid close attention to 
various perspectives and respect issues in academia related to academic freedom, work load and other strategies already in use in foundational courses. Still, our long term goal supports the faculty of education's re-visioning and restructuring impetus promoted by our university's Dean.

\section{Impact for Work of the Ontario College of Teachers}

This collaborative professional learning project illustrated the value of partnerships for supporting the Ontario College of Teachers' efforts to assist in the meaningful integration of the standards and case pedagogy within initial teacher education. This particular project was successful because it involved the following three key components:

- the presence of a highly committed faculty member who was responsible for facilitating significant programmatic change through a foundations course

- the visible support for the change provided by the Dean in the teacher education program

- relevant resources and the involvement of external partners who were equally committed to the institutional change initiative.

This project holds implications for the future work of the Ontario College of Teachers as related to the standards and initial teacher education. Participant feedback identified multiple uses of the case institute. These included:

- the value of case protocol for their professional learning

- the relevance of the College's resources for their practice

- the importance of authentically integrating the standards within teacher education courses

- the acknowledgement that teachers have an important role to play in developing policy: that their words and narratives formed the bases for the standards and College's resources

- the new understanding they had gained regarding the role of the College's body to work with faculties and individual teachers.

\section{Faculty Professional Learning Community}

The format of full day experiential institutes has been strongly supported by faculty members as effective professional learning. These teacher educators commented on the importance of having "time to share and discuss with colleagues" in order "to reflect on how the standards can be woven into practice". Faculty also identified professional learning that incorporates dialogue, reflection and collaboration to promote appropriate and engaging professional learning opportunities for educators at multiple career levels: pre-service, in-service, and principals. The institute modeled, in this manner, a constructivist and reflective approach to learning about and unraveling the complexities of teaching.

\section{Standards Resources}

The Ontario College of Teachers' standards resources were extremely well received by the teacher educators. They described them as being "a fabulous document", "very professional resources", "top quality", "relevant" and "creative, telling, practical and inspiring". These inquiry based resources were viewed as highly applicable for teacher education. The faculty was extremely eager to begin using these materials in their courses. 


\section{Standards}

The orientation sessions that described how to implement the standards into practice were identified as "wonderful", "very professional", "rich" and "easy to understand especially with the graphic organizer layouts". The core significance of standards for teacher education was identified by many faculty members. They indicated that they had gained considerable understanding and insight into the foundational role of the standards for initial teacher education. The teacher educators also strongly validated the potential use of case inquiry for supporting the formation of teacher candidates. Many stated that they were eager to integrate the case protocol immediately into their courses. Some felt that they could build on the presentation by incorporating on-line or technology aspects into their work with teacher candidates.

\section{Conclusion}

Through partnership, the Faculty of Education at Brock University University and the Ontario College of Teachers became a network for faculty members and Ontario College of Teachers staff to exchange views and strategies related to case study pedagogy (Shulman, 1992; DarlingHammond, 2006). Establishing this authentic relationship was pivotal in fostering the theory practice knowledge that exists not only for faculty, but that also needs to unfold for our future teacher candidates and the teaching profession (Stephens \& Boldt, 2004).

We feel that our partnership has been successful because it involved a unique collaboration, a sense of collegiality and trust, and a shared leadership in the process (Martin, Reeves, Wilson, O’Dell, \& Egan, 2004). Evidence of this was seen in: the presence of a committed faculty member who had been assigned the responsibility for facilitating significant programmatic change; the visible support for the change provided by the Dean of Brock University in the teacher education program; the involvement of external partners who were equally committed to the initiative of institutional change through the use of case pedagogy. Recently, case pedagogy has been lauded as effective and necessary for building teacher candidate knowledge (Darling-Hammond, 2006). We could not agree more. Because we critically reflected before, during and after the process and delivery of the case study institute, we were open to further possibilities and to branch our experience outwards and forward in order to maintain a highly successful partnership (Peel, Peel, \& Baker, 2002).

We hope our partnership and the links we have made by reflecting on our collaboration through self-study and reflection, serves as an example to other educational institutions and the potential impact and success such partnerships may bring. In our case, we reflected on the partnership between a university and a self-regulatory body. Many other partnerships are as important. Collectively, the partnership within this collaborative venture provides a model with important considerations for other universities, school systems, and stakeholders interested in fostering effective partnerships (Ciuffetelli Parker, Fazio, Volante \& Cherubini, 2008; Glenn, 2001; Holmes Group, 1995). Teacher education has indeed evolved into a cooperative responsibility by many, especially given the recent emphasis on educational reform (see for example Beck \& Kosnik, 2006; Cole, 2000; Darling-Hammond, 2006; Sutherland, Scandlon, \& Sperring, 2004). More than ever, partnerships that are based on relationship matter (Ciuffetelli Parker et. al, 2008). By building professional relationships between such learning groups as universities, school districts, regulatory bodies, governments, and teacher associations, what 
transpires is a "collective leadership in teacher education issues; a sense of belonging...and individual contributions which are listened to and supported by the learning group" (Ciuffetelli Parker et. al, 2008, p. 39). 


\section{References}

Beck, C., \& Kosnik, C. (2006). Innovations in teacher education: A social constructivist approach. Albany, NY: SUNY Press.

Bullough, R.V., \& Pinnegar, S. (2001). Guidelines for quality in autobiographical forms of selfstudy research. Educational Researcher, 30, 13-21.

Bruner, J. (1990). Acts of Meaning. Cambridge, Ma: Harvard Press.

Carter, K., \& Doyle, W. (1987). Teachers' knowledge structures and comprehension processes. In J. Calderhead (Ed.), Exploring teachers' thinking. London: Cassell.

Ciuffetelli Parker, D., Fazio, X., Volante, L., \& Cherubini, L. (2008). Relationship matters: Negotiating and maintaining partnerships in a unique teacher education program. Action in Teacher Education, 30(3), 39-53.

Cochran-Smith, C. (2002). Learning and unlearning: The education of teacher educators. Teaching and Teacher Education, 19, 5-28.

Cochran-Smith, M., \& Lytle, S.L. (1990). Research on teaching and teacher research: The issues that divide. Educational Researcher, 19(2), 2-11.

Cole, A. L. (2000). Toward a preliminary understanding of teacher education reform in Anglophone Canada. McGill Journal of Education, 35(2), 139-54.

Connelly, M. F., \& Clandinin, D. J. (1988). Teachers as curriculum planners: Narratives of experience. New York: Teachers College Press.

Darling-Hammond, L. (2006). Powerful teacher education: Lessons from exemplary programs. San Francisco: Jossey-Bass.

Dewey, J. (1938). Experience and Education. New York: Collier.

Dinkelman, T. (2003). Self-study in teacher education: A means and ends tool for promoting reflective teaching. Journal of Teacher Education, 54(1), 6-18.

Geertz, C. (1973). Thick Description: toward an interpretative theory of culture. In Geertz, C. (Ed.). The interpretation of cultures (pp. 3-30). New York: Basic Books.

Glenn, A. D. (2001). Lessons in teacher education reform: A comparative analysis of teacher education in the United Kingdom and the United States. Washington, DC: American Association of Colleges of Teacher Education.

Guskey, T. R. (2002). Does it make a difference? Evaluating Professional Development. Educational Research, March, pp. 45-51. 
Holmes Group. (1995). Tomorrow's schools of education: A report of the Holmes Group. East Lansing, MI: Author.

Korthagen, F., Loughran, J., \& Russell, T. (2006). Developing fundamental principles for teacher education programs and practices. Teacher and Teacher Education, 22, 1020-1041.

Korthagen, F. A. J. (2001). Changing our view of educational change. Teaching and Teacher Education, 17(2), 263-269.

Korthagon, F. (2004). In search of the essence of a good teacher: Towards a more holistic approach in teacher education. Teaching and Teacher Education, 20(1), 77-97.

Loucks-Horsley, S., Hewson, P., Love, N., \& Stiles, K. (1998). Ideas that work: Mathematical professional development. Colombus, Ohio: Eisenhower National Clearinghouse.

Loughran, J. J. (Ed.). (1999). Researching teaching: Methodologies and practices for understanding teaching. London: Falmer Press.

Loughran, J. J. (2004). A history and context of self study of teaching and teacher education practices. In J. J. Loughran, M. L. Hamilton, V. K. Kubler LaBoskey, T. Russell (Eds.), International handbook of self-study of teaching and teacher education practices, Part One (pp. 7-39). London: Kluwer Academic Publishers.

Martin, D., Reeves, W. E., Wilson, E., O’Dell, L., \& Egan, T. M. (March, 2004). Taking on the teacher supply and retention challenge: A performance focused model for schooluniversity partnerships. Paper presented at the Academy of Human Resource Development International Conference, Austin, TX.

McAninch, A. (1993). Teacher thinking and the case method: Theory and future directions. New York: Teachers College Press

Merseth, K. (1997). Cases in educational administration. US: Addison-Wesley

Merriam, S.B. (2001). Qualitative research and case study applications in education. San Francisco: Jossey-Bass.

Moustakas, C. (1994). Phenomenological research methods. Thousand Oaks: Sage.

Newman, J. M. (1987). Learning to teach by uncovering our assumptions. Language Arts, 6(7), 727-737.

Peel, H. A., Peel, B. B., \& Baker, M. E. (2002). School/university partnerships: A viable model. International Journal of Educational Management, 16(7), 319-325.

Perkins, D. N., \& Saloman, G. (1988). Teaching for transfer. Educational Leadership, 46(1) 
Richert, A. E. (1991). Case methods and teacher education: Using cases to teach teacher reflection. In B. R. Tabachnick \& K. Zeichner (Eds.), Issues and practice in inquiryoriented teacher education (pp. 130-150). London: Falmer Press.

Rust, F. O. (1999). Professional Conversations: New Teachers Explore Teaching through Conversation, Story, and Narrative. Teaching and teacher education. 15, 367-380.

Stephens, D., \& Boldt, G. (2004). School/university partnerships: Rhetoric, reality, and intimacy. Phi Delta Kappan, 85(9), 703-07.

Shulman, J. H. (Ed.). (1992). Case methodology in teacher education. New York: Teachers College Press.

Shulman, J., Whittaker, A., \& Lew, M. (2002). Using assessments to teach for understanding: A casebook for educators. New York: Teachers College Press.

Sutherland, L. M., Scanlon, L. A., \& Sperring, A. (2004). New directions in preparing professionals: Examining issues in engaging students in communities of practice through a school-university partnership. Teaching and Teacher Education, 21, 79-92.

Sykes, G., \& Bird, T. (1992). Teacher education and the case idea. Michigan State University: National Center for Research on Teacher Learning.

Zeichner, K.M., \& Noffke, S.E. (2001). Practitioner research. In V. Richardson (Ed.), Handbook of research on teaching (pp. 298-332). Washington, DC: American Educational Research Association. 